\title{
A PAIXÃO SEGUNDO G.H.: UMA (RE) LEITURA DO ROMANCE DE CLARICE LISPECTOR
}

\author{
Aline Costa da Silva ${ }^{1}$
}

\begin{abstract}
RESUMO
Este estudo se propõe a trazer ao debate uma experiência de leitura do romance de Clarice Lispector, $A$ Paixão Segundo G.H. Assim, intenta interpretar a obra a partir dos horizontes externos e internos, considerando a sua paratextualidade fundante, comentários sobre o livro e sua circulação. Ainda, dialoga com outros leitores da obra, corroborando para o alargamento do horizonte de expectativas inicial, no qual o fluxo da consciência, a transgressão, a busca do nada e o fomento de uma dialética negativa circunscrevem a verdadeira existência humana. Para isso, considera os construtos teóricos referentes à História do livro, de Robert Darton (1995), da paratextualidade de Genette (1982), da Estética da Recepção, de Hans Robert Jauss (1994), da filosofia existencialista da Sartre (2018), Heidegger (1988) e, ainda, da dialética negativa proposta por Theodor Adorno (2009). Em suma, compreende o romance enquanto metaforização da vida, que se dá pela oposição social, em prol da superação da alienação, no mergulho do subsolo da (in)consciência para, enfim, descontruir os enganos e percepções superficiais da existência.
\end{abstract}

Palavras-Chave: A Paixão Segundo G.H. Fluxo. Negação. Existencialismo. Metaforizarão.

\begin{abstract}
This study proposes to bring to the debate an experience of reading the novel by Clarice Lispector, The Passion According to G.H. Thus, it tries to interpret the work from the external and internal horizons, considering its founding paratextuality, comments about the book and its circulation. Still, it dialogues with other readers of the work, corroborating the extension of the initial horizon of expectations, in which the flow of consciousness, transgression, the search for nothing and the promotion of a negative dialectic circumscribe the true human existence. For this, he considers the theoretical constructs referring to Robert Darton's (1995) book history, Genette's (1982), Hans Robert Jauss's Aesthetics of Reception (1994), Sartre's (2018) existentialist philosophy, Heidegger (1988) and the negative dialectic proposed by Theodor Adorno (2009). In short, he understands the novel as a metaphorization of life, which is given by the social opposition, for the sake of overcoming alienation, in the subsoil dive of (in) consciousness, in order to finally dismantle the superficial mistakes and perceptions of existence.
\end{abstract}

Key Words: The Passion According to G.H. Flow. Negation. Existentialism. Metaphor

\section{INTRODUÇÃO}

\begin{abstract}
Ah, mas ao mesmo tempo como posso desejar que meu coração veja? se meu corpo é tão fraco que não posso encarar o sol sem que meus olhos fisicamente chorem - como poderia eu impedir que meu coração resplandecesse em lágrimas fisicamente orgânicas se em nudez eu sentisse a identidade: o Deus? Meu coração que se cobriu com mil mantos. (LISPECTOR, 2010, p. 64).
\end{abstract}

Ler é já uma experiência, experimentação do outro, dos sentidos, representações e simbologias conferidas ao mundo e a tudo o que nele há. É, portanto, um diálogo em que mentes se entrecruzam para além da materialidade e percorrem os caminhos tortuosos que, a

\footnotetext{
${ }^{1}$ Doutoranda em Estudos Literários-PPGL/UFPA. E-mail: alineclau_cs@yahoo.com.br
} 
exemplo dos desenhos encefálicos, formam labirintos e podem alcançar profundidades desconhecidas, encontros de si neste mesmo desconhecimento... exatamente o que acontece quando se lê Clarice Lispector.

Sua obra, reconhecida pela inovação de uma narrativa poética, pelo fluxo da consciência, tal como se observa em A Hora da Estrela e O Lustre, ganha fôlego propiciando um mergulho ainda mais profundo em A Paixão Segundo G.H., cuja leitura ergue, neste estudo, a ponte que liga dois abismos intransponíveis: o tudo e o nada. Assim, atravessá-la significa correr o risco de sair do 'tudo' e descobrir o 'nada', assim como, ao fazê-lo, perderse durante a busca de sua compreensão.

A escolha da obra para a experiência de leitura antes anunciada se deu para cumprir os protocolos disciplinares. Não obstante, em sua concretização, a desorganização de G.H encontrou-se com a minha, até então sentida, mas não compreendida. Encontros de paixões? Filosofia existencialista em debate? Ida ao inferno? Releituras de si? Cada pergunta surgiu como quatro pedaços da maça mordida, inferindo visitações na mente da narradora e a descoberta de que o "inferno (também) é o meu máximo" - minha adaptação (CLARICE LISPECTOR, 1998, p. 125-126).

Seguindo a metaforização proposta pela autora, o inferno, que é o 'saber', será aqui organizado por quatro mordidas no fruto do conhecimento, aquele que expulsa o homem do paraíso, quatro apontamentos, como propõe Antônio Candido (1989), para uma experiência nada inofensiva de leitura. A primeira delas se subscreve nessas linhas introdutórias, onde permito-me a presença mais direta para justificar o encontro dialógico entre o eu e a obra, diga-se, a temática que é particular à narradora, mas que dialoga com o eu-leitor.

A segunda mordida, primeiro contato com a superfície da casca e as demais camadas da fruta/texto, dedica-se ao "comentário", o que o crítico compreende como uma espécie de tradução-externa, informativa, objetiva, mas que funciona como o vestíbulo da interpretação (CÂNDIDO, 1996, p. 15). Nele, como leitora em busca do 'nada', acrescentei teorias que julguei colaboradoras para a interpretação da obra, como as que tratam da História do livro, segundo Robert Darnton (1995), dos Paratextos, conforme Gerard Genette (1982), da Estética da Recepção, de acordo com Karlheinz Stierle (1979) e Hans Robert Jauss (1994).

A terceira mordida explicita o horizonte de expectativa inicial frente a obra, deslindando os acontecimentos que demarcam o evento no romance. Para tal, é preciso detalhar o livro, objetivando sua estrutura e conteúdo, o que vai incidir diretamente na interpretação final. A quarta, dessa vez suculenta e que dá o gosto do sumo da obra, dedica-se 
ao alargamento do horizonte, outra "interpretação" indivisível ao comentário, posto que o caldo se extrai após moída e esmiuçada a matéria.

Para Antônio Cândido, “interpretar significa reproduzir e determinar com penetração compreensiva e linguagem adequada à matéria, a estrutura íntima, [...], segundo as quais uma obra literária se processa, se divide e se constitui de novo como unidade" (CÂNDIDO, 1996, p. 16). A partir desse pensamento, nesta experiência de leitura a interpretação posta será uma dentre as infinitas possibilidades de ver/existir a obra, de saber/fazer as consequências de sua penetração. Embora o texto de Antônio Cândido, aqui eleito para a experiência de leitura, tratar-se de "estudo analítico do poema", ele é oportuno e satisfatório para guiar o mergulho (dada a profundida) e a mordida (pelo gosto e prazer), inerentes ao romance lispectiano.

\section{A PAIXÃO SEGUNDO G.H.- COMENTÁRIOS}

Conforme os estudos de Robert Darnton (1995), compreender a história de um livro e todos os elementos que compõe o circuito de comunicação é importante para reconhecer a figura que encerra todo o processo que envolve a sua produção, edição, circulação e a recepção: O leitor. Ele é responsável não apenas pela leitura da obra, mas pela atuação que exerce antes e depois de sua composição.

Considera-se que no tempo de sua publicação, os leitores de A Paixão segundo G.H. eram em sua maioria universitários. Esse fato, além da boa crítica que a obra recebeu, bem como sua tradução para outras línguas, contribuiu para que ela tivesse uma boa circulação e aceitação do público. O romance obteve cinco edições ainda enquanto Clarice Lispector era viva: a segunda e a terceira edição, 1968 e 1972 respectivamente, foram publicadas pela Editora Sabiá. Por sua vez, a quarta edição e a quinta, de 1974 e de 1976, foram publicadas pela José Olympio.

Bem prestigiada, a Editora Sabiá era de propriedade de Fernando Sabino e de Rubem Braga. Fruto do rompimento com a Editora do Autor, mais tarde foi vendida para a José Olympio. Desse modo, desde a editora, as traduções, o público leitor, todo o circuito de produção da obra contribuiu para a sua boa circulação, considerável recepção, reconhecimento e consequente canonização.

A edição utilizada para essa experiência de leitura é a publicada pela editora Pacco, publicada no Rio de Janeiro, em 1998. Sobre esse livro, falam seus paratextos que fornecem inferências desde a sua capa. Sobre eles, outras considerações: 


\subsection{OS PARATEXTOS}

Gérard Genette (1982, p. 10), afirma que a paratextualidade se constitui de elementos importantes do livro, situados em suas franjas, importantes para interpretação do "todo" da obra por demarcarem o espaço estratégico de diálogo, de impressões e marcas dialógicas no texto. Constituem os paratextos:

Título, subtítulos, intertítulos; prefácios, preâmbulos, apresentação, etc.; notas marginais, de rodapé, de fim; epígrafes; ilustrações; dedicatórias, tira, jaqueta [cobertura], e vários outros tipos de sinais acessórios [...] que propiciam ao texto um encontro (variável) e às vezes um comentário, oficial ou oficioso, do qual o leitor mais purista e o menos inclinado à erudição externa nem sempre pode dispor tão facilmente quanto ele gostaria e pretende51 [GENETTE, 1982, p. 10].

A começar pela capa, esta contém o nome da escritora logo acima, com fontes destacadas, isso porque a escritora, por seu prestígio e reconhecimento junto à crítica e o público, agrega valor à sua própria obra. Em seguida se tem o título, colocado ao lado da gravura que tem uma mulher cabisbaixa, ou entregue, tomada pela lateral esquerda de sua face por uma luz e acima dela a barata que serve como ponto de partida para a maior de suas maiores introspecções.

Diferentemente, a capa da primeira edição dá o primeiro destaque ao título da obra e somente depois se escreve o nome da autora. O que chama atenção é que é anunciado, acima do nome da editora, o gênero a que a obra pertence: Um romance, e assim o leitor é preparado, sem saber que o próximo paratexto o tirará de sua 'zona literária confortável'.
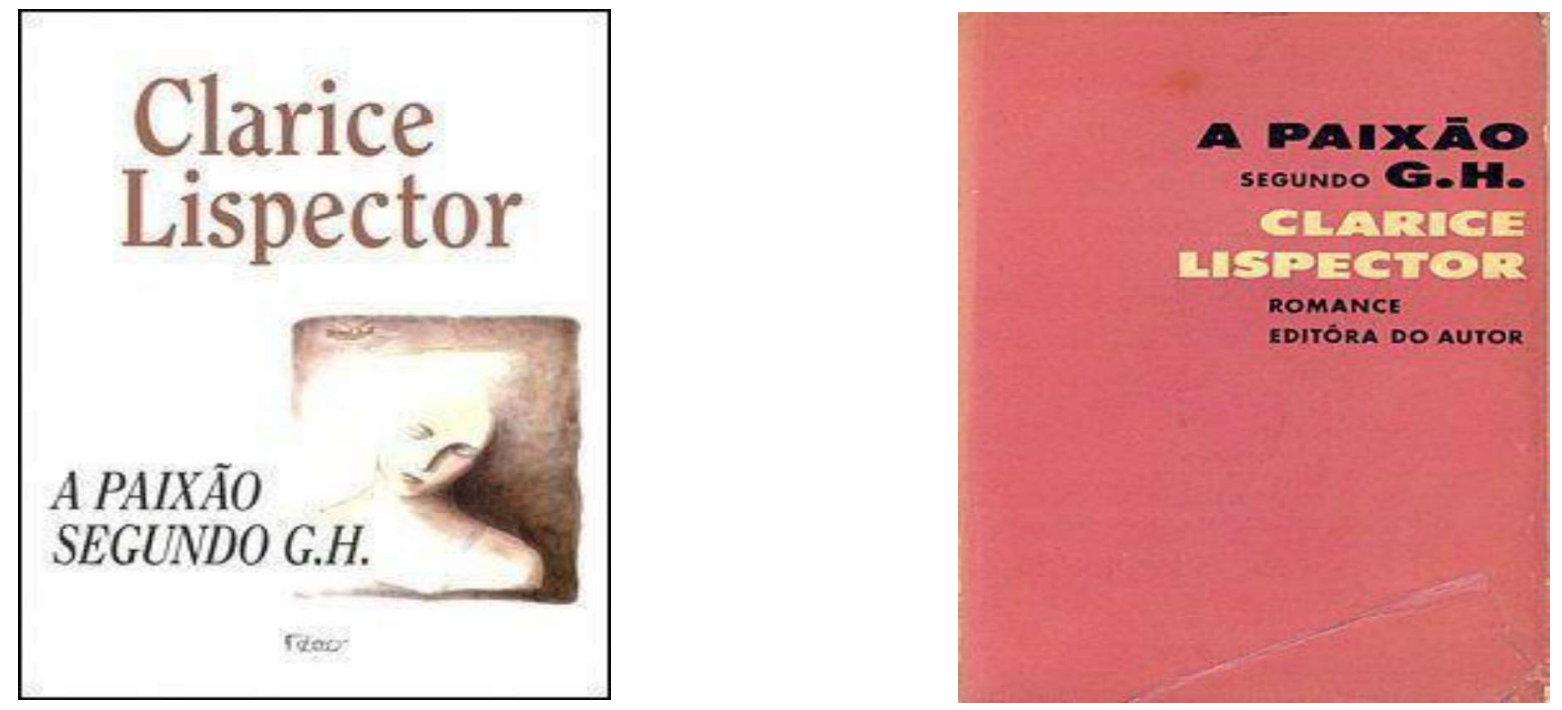
A orelha, assinada por José Castello, revela ao leitor um livro com aspecto epifânico. A contracapa fala de narrativas que sublinham a precariedade e o nomadismo da consciência e da existência, entre as aleluias e as agonias de Ser. Não obstante, uma nota prévia de Marlene Gomes Mendes justifica que a edição busca sanar as incorreções que se fizeram na obra ao longo do tempo, contrariando o romance original de Clarice Lispector, antes no mesmo texto apresentada como dedicada à sua escrita.

Em prefácio, Clarice Lispector define o seu leitor e com ele dialoga:

Este livro é como um livro qualquer.

Mas eu ficaria contente se fosse lido apenas por pessoas de alma já formada.

Aquelas que sabem que a aproximação, do que quer que seja, se faz gradualmente e penosamente - atravessando inclusive o oposto daquilo que se vai aproximar. Aquelas pessoas que, só elas, entenderão bem devagar que este livro nada tira de ninguém.

A mim, por exemplo, o personagem $\mathrm{G}$. $\mathrm{H}$. foi dando pouco a pouco uma alegria difícil; mas chama-se alegria.

C.L.

O futuro/presente mergulho no mundo da subjetividade se anuncia com a epígrafe de Bernard Berenson: "A complete life may be one ending in so full identification with the nonself that there is no self to die".

Então a narrativa se inicia, tal como termina: “

\subsection{A RECEPÇÃO}

A recepção da obra é importante para compreender o impacto que ele exerce junto ao leitor. Conforme os construtos teóricos de Hans Robert Jauss, que em 1967 proferiu na escola de Constança palestra intitulada "O que é e com que fim se estuda a história da literatura?", a importância de uma obra não se dá por seu posicionamento no cânon. Como afirma,

[a] qualidade e a categoria de uma obra literária não resultam nem das condições históricas ou biográficas de seu nascimento, nem tão-somente de seu posicionamento no contexto sucessório no desenvolvimento de um gênero, mas sim dos critérios da recepção, do efeito produzido pela obra e de sua fama junto à posteridade (JAUSS, 1994, p. 8).

A partir da asserção, considera-se importante citar alguns, dentre os muitos leitores de Clarice, que falam sobre A Paixão segundo G.H. Antônio Cândido é o primeiro deles, para 
quem Clarice Lispector traz algo de novo para a literatura, cuja empenho faz com que o indefinido seja posto na obra. Em sua compreensão, o valor do romance da escritora está na sugestão, na simbologia que desnuda o homem, tudo realizado com minucia de detalhe.

A força desta escritora parece estar na capacidade de manipular os detalhes, que vão se juntando para formar a narrativa e sugerir o mundo, sem que haja necessidade de uma estruturação rigorosa. Daí a fluidez imprecisa que dissolve muitas das suas histórias, ou, pelo contrário, o destaque luminoso que elas ganham na intimidade sugerida pela ampliação do pormenor (CANDIDO, 1999. p. 91)

Benedito Nunes (1996), em "O Drama da Linguagem", afirma que a obra foi recebida pela crítica com um silêncio "que, quebrado por uma ou outra apreciação, ainda não foi devidamente avaliado quanto ao lugar que ocupa na prosa de ficção da extraordinária escritora" (...). Ressalta que tal crítica chegou a falar acerca do hermetismo da autora e que, por fim, dada a sua profunda introspecção, resultam na "incomunicabilidade final dos propósitos da romancista" (NUNES, 1966, p. 11).

Segundo Assis Brasil (1973), A Paixão segundo G.H revela ao leitor "uma autora que se inscreve aqui como um dos nomes que constroem uma obra dentro de nova mentalidade e novos recursos estéticos" (BRASIL, 1973, p. 76). Para o crítico, o romance transpassa o campo da ficção para adentrar o do conhecimento, o que pode ser mensurado pelo monólogo de G.H. que leva à inferência gnóstica/filosófica da existência.

Por sua vez, Américo Motta Pessanha, no ensaio "Itinerário da Paixão" (1965), afirma que o percurso de A paixão segundo G.H., é construído nas demais obras de Clarice Lispector. Como afirma, " obra clariceana, abriga a gestação de uma visão de mundo que só podia terminar em A paixão. Uma espécie de itinerário oculto, em busca da raiz do ser-em-si (PESSANHA, 1965, p. 23). O leitor trata A Paixão como o subsolo da obra clariciana, após dada a superfície anterior de contos, crônicas e outros escritos.

Dado a relação de H.G. com a empregada, Oliveira (1985) chama atenção para um embate de classes perceptível no modo em que a personagem vê beleza na barata, mas repugna a sua empregada, dando espaço a "viseira ideológica que a vinha impedindo de ver sua antiga empregada como um outro ser humano, em vez de um simples objeto de exploração. (Oliveira, 1985: 94). Nesse aspecto, o pensamento de que o quarto da empregada seria o mais sujo e, mais adiante, o desenho por ela tracejado de G.H na parede, remontam a oposição social entre as duas personagens.

Olga de Sá compreende os aspectos paródicos em A Paixão segundo G.H. Para a leitora, o apartamento, a barata e tudo o quanto está contido no romance apresentam-se como 
paródias da vida, "cujas reflexões e angústias metafísicas ironiza? (SÁ, 1988, p. 219). Nesse sentido, depreende-se que G.H. é uma metáfora de Clarice que vai experimentando-se não apenas na configuração da personagem redonda, mas na arquitetura da própria escrita experimental do romance.

Certamente, outras leituras e infinitas interpretações subsistem na recepção do romance lispectiano. Os explicitados acima dão o gosto necessário às novas mordias no fruto do conhecimento, aquele expresso em diversas vertentes em A Paixão Segundo G.H: filosófico, religioso e/ou seus contrários, místico, gnóstico, entre outros. Cada uma dessas leituras cumpre o afirmado nas teses de Hans Robert Jauss, de que na interação dos aspectos diacrônicos e sincrônicos da obra, a obra literária é atualizada pelo leitor desse e de outros tempos e são esses leitores que sustêm o romance de Clarice Lispector no centro do debate.

\section{HORIZONTE DE EXPECTATIVAS INICIAL}

O romance A Paixão segundo G.H. (1964) é considerado uma obra que reflete a maturidade da escrita literária de Clarice Lispector. Maturação no sentido de que ela reúne e condensa o que a escritora expressou e comunicou em obras anteriores, como nos romances Perto do Coração Selvagem (1943), O Lustre (1946), a Cidade Sitiada (1949) e A Maçã no Escuro (1961), última obra que antecede o romance publicado em 1964 e colabora para a sua compreensão.

O livro não possui capítulos distintos, em vez deles, o final e o início de cada nova percepção da narradora diante de si, da vida e do outro se dá pela repetição de uma oração realizada como uma prece, que precisa ser repetida para se fazer ouvir (-se). O enredo, aparentemente simplório, narra a história da protagonista reconhecida pelas iniciais G.H., uma escultora que mora em um apartamento de classe alta, uma cobertura no $13^{\circ}$ andar. Por ocasião da demissão de sua empregada, resolve faxinar a casa, começando pelo quarto da ex funcionária, por pensar ser ele o aposento mais sujo.

Ao adentrar no local e perder-se em reflexões sobre a condição humana, a personagem avista uma barata saindo do guarda-roupa, cuja porta a esmaga e a deixa rastejante com sua gosma branca escapando do corpo. G.H. resolve então provar a barata, enfrentar o nojo e a limitação humana para alcançar o antipecado e atravessar a sensação da morte. Nesse intervir, percebe-se um apelo às questões existenciais que podem ser entendidas, incialmente, ao modo pensado por Jean Poul Sartre, para quem a existência precede a essência, uma existência humana que não sublima a feiura ou o lado negativo do humanismo. 
Em continuidade, o filósofo representa um existencialismo ateu, afirmando: "Deus não existe. Há pelo menos um ser pelo qual a existência precede a essência, um ser que existe antes de poder ser definido por qualquer conceito; este ser é o homem, ou como diz Heidegger, a realidade humana (1970, p.4).

Nessa vertente, chama atenção, no romance, o momento em que a personagem se depara com um mural de carvão na parede, na qual há contornos de sua representação, seca, com poucos traços, perdendo em atenção apenas à figura da barata esmagada pela porta do guarda-roupa. Desde então, muitas reflexões filosóficas são feitas, até que G.H. imagina comer o inseto e seu musgo esbranquiçado, desafiando o nojo, voltando ao estado primitivo e, finalmente, desistindo de 'dizer'.

No que concerne a arquitetura da obra, os caracteres que a iniciam e a terminam são pontuações, hifens em gradação, estética que, para época em que o livro foi lançado, tratavase de uma inovação na estrutura do romance, apresentando A Paixão segundo G.H. como uma obra com veias experimentais que exige um adentrar cada vez mais atento no universo interno do texto, a ponto de ampliar as expectativas iniciais da leitura.

\section{O ALARGAMENTO DO HORIZONTE}

“[...] toda vida é uma missão secreta” (LISPECTOR, 1998, p. 175)

A (re)leitura:

“------------Estou procurando, estou procurando. Estou tentando entender. Tentando dar a alguém o que vivi e não sei a quem, mas não quero ficar com o que vivi. Não sei o que fazer do que vivi, tenho medo dessa desorganização profunda" (CLARICE LISPECTOR, 2010 , p. 9). No romance, a narradora apresenta os primeiros mergulhos em seu mundo interior, o eu apoiado pelas três pernas que anuncia, cuja vida, vivida e vista, anseia opor-se à organização que a circundava e que estabelecia a monotonia da lógica.;

Perdi alguma coisa que me era essencial, e que já não me é mais. Não me é necessária, assim como se eu tivesse perdido uma terceira perna que até então não me impossibilitava de antar mas que fazia de mim um tripá estável. Essa terceira perna eu perdi. E voltei a ser uma pessoa que nunca fui. Voltei a ter o que nunca tive: duas pernas. Sei que somente com as duas pernas é que posso caminhar. Mas ausência inútil da terceira me faz falta e me assusta, era ela que fazia de mim uma coisa encontrável em mim mesma, e sem sequer precisar me procurar. (LISPECTOR, 2010, p.9 e 10) 
O que G.H realiza é uma consciência individual e uma experiência transgressora. O complexo processo de pensamento da personagem se realiza com uma espécie de gradação reversa, um mergulho em profundezas psíquicas, que a medida em que penetra no interior, ganha nuances de cinza até alcançar a tonalidade branca, a não cor, o mais profundo estado de uma consciência que precisa da desorganização para se encontrar.

Do exposto, pode-se compreender o romance em dois estágios: Em primeiro lugar, o (des)encontro de G.H consigo, que a faz perceber o significado da vida pelas ausências, como no episódio da mão decepada do seu ex-namorado, que se dizia ajudante, mas que, incorpóreo, configurava a maior das negações e que leva a personagem do purgatório da vida real ao inferno da existência: o profundamente real.

Assim, o mergulho na consciência da personagem dá-se no decorrer da leitura do romance, a qual se aprofunda ao (per)seguir as camadas da narrativa:

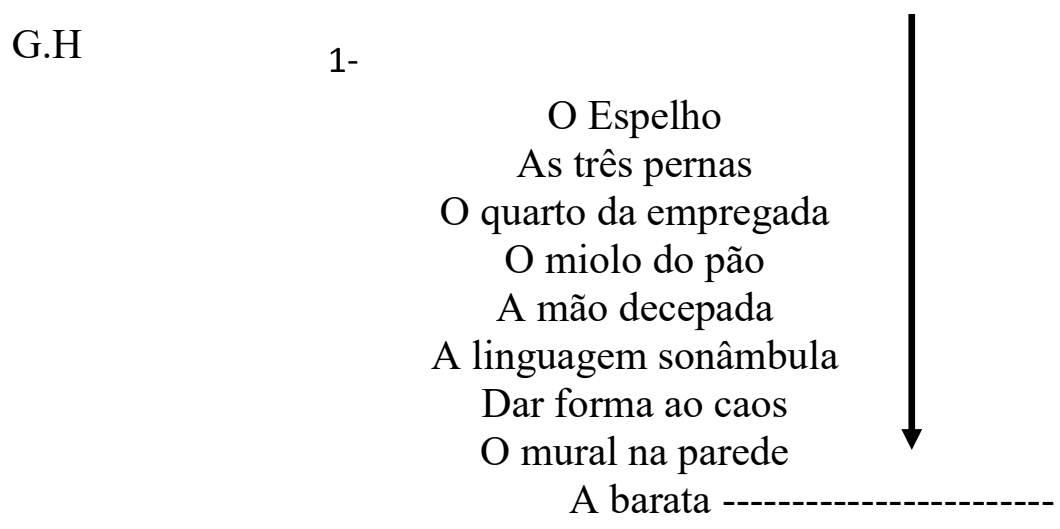

Em segundo lugar, G.H. realiza o mergulho no reverso, o que pode ser compreendido pela via da dialética negativa de Theodor Adorno (1966), de uma metafísica em queda que busca a verdade na precariedade e não na aparente organização da superfície. Segundo afirma o filosofo, "qualquer um, inclusive as que se ocupam com negócios desse mundo, considerará um desvario a ideia de que esse mundo finito de tormento infinito seja abarcado por um plano universal divino" (ADORNO, p. 375.)

Nesses termos, após se desconstruir, a personagem realiza, finalmente, o encontro com o seu particular, negando o impulso religioso que outrora acenava para uma transcendência divina, prenunciando angústia da personagem que, no oposto da paixão do Cristo morto para a redenção do homem e sua elevação ao reino divino, configura-se na paixão de G.H., que simbolicamente morre para viver, a ponto de chegar ao entendimento de que o nada é o tudo existencial. 
Assim, o que se tem, nesse caso, é uma teologia invertida, concretizada na existência não do sobrenatural, mas da subjetividade e no contexto da cotidianidade da personagem. Consoante à essa subjetividade, a barata é o elemento de passagem para o mundo ainda mais subterrâneo, para a consciência primitiva da personagem. A partir da aparição do inseto, o mergulho de G.H. se aprofunda e o romance atinge um segundo estágio:

2- $\quad$ O Imundo proibido
O Deserto- nada/neutro
A vida x o Sal
O Nada
O tempo presente
A liberdade x a Culpa
O inferno
O Amor x o Pecado original
O Erro x a Verdade
A Amplidão
O Mercado
Deus
O Gosto do vivo
O Eu/Barata
O núcleo
A Desistência de dizer

Em analogia à leitura de Pessanha (1965), que trata do romance como o subsolo da obra de Clarice Lispector, a diagramação superposta representa-se, neste estudo, como se fossem camadas planetárias. Quando a personagem solta a terceira perna, diante do espelho ela se possibilita a vivência da primeira descontinuidade, até que pouco a pouco os mantos que a ligam à terra/mundo interior são transpassados e alcançados.

Desse modo, o quarto da empregada, o miolo do pão, a representação da mão decepada, a linguagem sonambula, o mural na parede e a visão da barata, a priori vislumbrada como "pura sedução- Cílios, cílios pestanejando que chamam" (LISPECTOR, 2010, p. 59), são fases de um mergulho sem volta: "não havia uma queda, havia apenas um grau a menos daquilo que eu era com os outros, e isso sempre foi a minha [...] espécie de beleza" (LISPECTOR, 2010, p. 24).

$\mathrm{Na}$ segunda descontinuidade, o mundo proibido é o inferno, lugar onde se confrontam todos os pares opositivos que se fazem representar no romance, desde os conflitos existências de G.H aos embates de classe que se desenham na parede e que dizem à patroa sobre o ódio mudo da empregada. Caída no abismo, G.H. pensa: 
O mundo havia reivindicado a sua própria realidade, e, como depois de uma catástrofe, a minha civilização acabara: eu era apenas um dado histórico. Tudo em mim fora reivindicado pelo começo. Eu passara a um primeiro plano primário, estava no silêncio dos ventos e na era de estanho e cobre - na era primeira da vida. [...] a pior descoberta foi a de que o mundo não é humano, e de que não somos humanos (LISPECTOR, 2010, p. 68).

Assim, chegar ao núcleo da consciência é tão fundo que, pela impossibilidade, denota devaneio extremado e por ele uma danação, uma presença 'demoníaca', no sentido da nãohumanidade: é o não-belo construído e que desconstrói a forma primitiva. No abismo da personagem, a claridade própria do núcleo interno, o branco que não é cor reflete, assim, o estado mais profundo da humanidade. Para atingi-lo é necessário cavar, sujar-se com o húmus do humano, deparar-se com as durezas interiores, vencer o calor que seca o húmido do húmus, o inferno que é saber. Neste clarão que é o neutro, o romance tem seu desfecho:

"Pois como poderia eu dizer sem que a palavra mentisse por mim? Como poderei dizer senão timidamente assim: a vida se me é. A vida se me é, e eu não entendo o que digo. E então adoro. "(CLARICE LISPECTOR, 1998, p.179)

Quanto aos tracejados presentes no romance, dão vazão à imagem do caminhar da barata. No início da obra, o caminhar se antepõe a primeira palavra que sai do pensamento de G.H (conf. p. 11). No interior da obra, já com corpo meio emergido, ela continua a andar (conf. p. 53). No desfecho, após o ponto que marca o final da fala, portanto da existência da personagem, os tracejados continuam (conf. p. 179).

A barata passeia na estrutura do romance, esmagada diante G.H. e resiste, com seu núcleo esbranquiçado e primitivo, os milênios. Comê-la é uma abdicação da organização e da beleza, a qual, na verdade, desorganiza e enfeia o mundo, posto que nega a verdadeira face da vida que é composta, sobretudo, da negatividade, da decepção e do estranhamento ao encontrar o nada.

Assim, é perceptível no romance uma teologia reversa, considerando-se que no conhecimento religioso tudo se cria a partir do verbo. No caso de G.H., desistir de dizer significa negar esse verbo e valorizar o vazio, o caos que existia no princípio, substituindo a ideia da transcendentalidade pelo subjetivismo da individualidade humana.

\section{CONSIDERAÇÕES FINAIS}

A paixão segundo G.H é um romance tecido a partir de pensamentos filosóficos, sobre os quais concorda Benedito Nunes (1973) ao analisar a obra de Clarice Lispector. Desses pensamentos, o existencialismo que se deslinda em Ser e Tempo, de Heidegger, é basilar, pois 
G.H está em busca não apenas do sentido, mas da natureza do ser. Daí a ânsia da narradora em mergulhar cada vez mais profundo em busca das "experiências originárias em que foram obtidas as primeiras determinações do ser" (HEIDEGGER, 1988, p.51).

Para isso, a linguagem age como uma sonâmbula, evidentemente porque a narrativa, com contornos oníricos, busca, em conformidade com as teorias psicanalíticas de Sigmund Freud, a inconsciência e o corpo em repouso. Tal condição de sonambulismo representa os raios de uma consciência, não é uma fronteira, mas uma posição limiar entre o mundo criado e o imaginado, entre a organização e a desorganização, enfim, entre o estado atual e o estado primitivo onde está a essência do ser que se chama subjetividade.

Para STEIN (1973, p.158-9), o Dasein, o ser em sua existência concreta, não se dissocia do idioma no qual se expressa. A linguagem sonâmbula, da narradora, tanto quanto a estética que o romance lispectiano inaugura, é o meio pelo qual o mergulho em busca da existência se realiza. O lógus é discurso (HEIDEGGER, 1988, p.62), a essência do ser é a palavra dita e G.H sente necessidade de gritar, de dizer, já que o ser está para além da palavra: ele é o dizê-la.

Nesta perspectiva, a narradora apresenta, portanto, comportamento que revela a angustia da sua existência, a qual se faz saber e sentir pela palavra não proferida. Essa angustia se dá por uma procura que primeiramente se orquestra para fora de si, está na crosta do mundo, antes da primeira descontinuidade. Nesse sentido, o conceito de angústia postulado por Kierkegaard (1844) cabe com inteireza em A Paixão, pois a angústia está justamente na busca exterior da essência humana. Encontrá-la seria o retorno ao neutro, contrário a máxima bíblica de que no "princípio era o verbo "-João, Cap.1, vers. 1.

Como diz o filósofo, a angústia dá vazão ao desespero, o qual se pode perceber no vômito de G.H (CLARICE LISPECTOR, 1998, p.64, 65, 111, 112, 113, 114). Há um deus no interior do homem e não é o criado pelas instituições. $\mathrm{O}$ vômito bota para fora, esvazia o ser de sua organização criada, abrindo espaço para uma nova alimentação. Vale ressaltar que essa "náusea" que leva ao vômito infere a obra de mesmo título do filósofo Jean-Paul Sartre. Quando o ser humano não encontra o sentido de sua existência ele enjoa, sente e fica perdido até que consiga compreender o que a própria náusea significa.

G.H se esforça para compreender a sua náusea e a sua existência. Há nela uma dialética negativa que existe, é vista, sentida e dita, de tal modo que o nada e o insosso se alinham no vazio onde pré-existe o humano. G.H. espelha o seu neutro reverso, seu desconhecimento até o fim inevitável. Comer a barata esmagada revelava para G.H a sua própria condição interior, o seu gosto na boca e a ideia de que, não importando a repulsa, seja 
da gosma do inseto ou do leite do peito materno, toda busca humana dá no nada, importando, portanto, o processo da busca mais do que o fim insípido da matéria experimentada.

Ainda, como se percebe no romance, a narradora dá importância ao líquido, à água que compõe o corpo e de onde ele nasce, contrariando o criacionismo de que tudo se fez pelo verbo. Nessa perspectiva, compreende que todo o líquido do corpo é sal, o qual, à parte da água, tem o gosto sentido nos lábios molhados pelas lágrimas.

Compreende-se que a obra realiza uma antítese social e revela um sujeito com sua não identidade, os paradoxos que circundam sua existência indefinida, uma dialética da ordem e da desordem, cuja movimentação extrai o mundo interno da personagem e a apresenta ao leitor. Assim, o exercício da narradora a leva a confrontar seu próprio estado de alienação para uma superação. Seu desejo era a sua emancipação, compreender a sua existência, mas não no viés do positivo ou do construído e sim do não, do negativo e da desconstrução. Não a propósito, a humanidade da personagem G.H (instituída pela linguagem) prescindi e "a desistência é uma revelação" importante: Não é o manifesto, mas o fracasso que é essencialmente humano, um nada adorado, posto que não importa o esforço da significação, o Ser sempre fracassa no que considera axiomático, criando, na verdade, mentiras que transforma em verdades.

Portanto, o inferno citado em muitos momentos do romance é retrato como a alegria, a apoteose do neutro propenso à G.H. Ela escolhe "não dizer", não dar à luz, não formar a vida, o reverso do que Deus representaria na gênese do mundo. Não obstante, para ela há alívio no caos, no não dizer o mundo sem mentir, porque a palavra não conseguiria expressar a verdade. A protagonista, ao destruir-se por inteira, descobre a neutralidade como fator primitivo e inerente à vida.

Finalmente, G.H. reverencia o desordenamento "A vida se me é. A vida se me é e eu não entendo o que digo. E então adoro. -“ (CLARICE LISPECTOR, 1998, p.179). No profundo em que mergulha, a personagem se queria, essencialmente, humana no mundo desumano, completamente muda, convertendo o que dantes era místico, no substrato da (própria) existência confrontada, descontruída e reerguida a partir do nada.

\section{REFERÊNCIAS}

ADORNO, Theodor w. Dialética negativa, Rio de Janeiro: J Zahar, 2009.

BARTHES, Roland. O prazer do texto. Tradução Jaime Guinsburg. São Paulo: Perspectiva, 1996. 
BOSI, Alfredo. História concisa da literatura brasileira. São Paulo: Cultrix, 2006.

BRASIL, Assis. História crítica da literatura brasileira: A nova literatura. I - O romance. Rio de Janeiro: Americana, 1973.

CANDIDO, Antônio. Vários Escritos. São Paulo: Livraria Duas Cidades, 1970.

Direitos Humanos e literatura. In: A.C.R. Fester (Org.) Direitos humanos E... Cjp / Ed. Brasiliense, 1989.

CARVALHO, Fabrícia Silva de. Fluxo de consciência na narrativa de a paixão segundo g.h, de Clarice Lispector, e Mrs. Dalloway, de Virginia Woolf. Brasília 2014. Disponível em: http://bdm.unb.br/bitstream/10483/8300/1/2014_FabriciaSilvadeCarvalho.pdf

COUTINHO, Afrânio. A literatura no Brasil. Rio de Janeiro: José Olympio, 2001.

DARNTON, Robert. O que é a história dos livros?. In: O beijo de Lamourette. Trad. Denise Bottmann. São Paulo: Companhia das Letras, 1995. p. 109-131.

HEIDEGGER, Martin. Ser e tempo. Trad. Márcia de Sá Cavalcante. Parte I. Petrópolis: Vozes, 1988.

JAUSS, Hans Robert. A história da literatura como provocação à teoria literária. São Paulo: Ática, 1994.

LIMA, Luis Costa. Por que literatura. Petrópolis: Vozes, 1966.

LISPECTOR, Clarice. A paixão segundo G.H. Rio de Janeiro: Rocco, 1964.

NUNES, Benedito. Leitura de Clarice Lispector. São Paulo: Quirón, 1973. 1995.

O drama da linguagem: Uma leitura de Clarice Lispector. São Paulo: Ática,

Oliveira, Solange Ribeiro de. A barata e a crisálida. Rio de Janeiro: José Olympio/PróMemória INL, 1985.

RODRIGUES, Fábio Della Paschoa. Os Calvários Cruzados de G.H. e Rodrigo S.M. Disponível em: http://www.unicamp.br/iel/site/alunos/publicacoes/textos/c00014.htm

PESSANHA, José Américo Mota. Clarice Lispector: O itinerário da Paixão. Cadernos Brasileiros, $\mathrm{n}^{\circ}$ 29, 1965. Disponível em: file://C:/Users/Aline/Downloads/8636576-6308-1SM.pdf

SÁ, Olga de. A Escritura de Clarice Lispector. Petrópolis: Vozes; Lorena: Faculdades Integradas Teresa D'Avila, 1979. 
SARTRE, Jean Paul. O Existencialismo é um Humanismo. Disponível em: http://stoa.usp.br/alexccarneiro/files/-1/4529/sartre_exitencialismo_humanismo.pdf. Acesso em 12.08. 2018.

STEIN, Ernildo. A questão do método na filosofia: um estudo do modelo heideggeriano. São Paulo: Duas Cidades, 1973.

FASCINA, Miiller Diego. MARTHA, Alice Áurea Penteado. A recepção crítica de Clarice Lispector: momentos decisivos. Revista do Programa de Pós-Graduação em Letras da Universidade de Passo Fundo - v. 11 - n. 1 - p. 92-109 - jan./jun. 2015. Disponível em: file://C:/Users/Aline/Downloads/4976-Texto\%20do\%20artigo-17469-1-10-20150826.pdf

Recebido em 17.04.2019

Aprovado em 17.04.2019 